\title{
列車が沿線近傍構造物を通過する際に発生する圧力波*
}

$\begin{array}{lllll}\text { 高 見 } & \text { 創*1, 菊 地勝 浩*1 } \\ \text { 飯 田 雅 宣*1, 前 川 } & \text { 博*2 }\end{array}$

\section{Pressure Waves Generated When a Train Passes a Nearby Structure}

\author{
Hajime TAKAMI*3, Katsuhiro KIKUCHI, \\ Masanobu IIDA and Hiroshi MAEKAWA \\ ${ }^{* 3}$ Railway Technical Research Institute, Environmental Engineering Division, \\ 2-8-38 Hikari-cho, Kokubunji-shi, Tokyo, 185-8540 Japan
}

\begin{abstract}
When a high-speed train enters or leaves a tunnel, impulsive pressure waves are radiated from the entrance/exit portal toward the outside of the tunnel. The waves are called a "micro-pressure wave," a "tunnel entry wave" and a "tunnel exit wave." A similar phenomenon occurs when a train passes a short structure in axial length in an open section (such as an over-bridge). We call it a "structure-passing wave." The length of the structure along the railway is several times or less the diameter of the structure cross-section. Although the structure-passing wave is weak at present, it could cause an environmental noise problem of a low-frequency (which has become public concem) as the train speed increases. This paper describes the characteristics of the structure-passing wave based on the results of model experiments and acoustic analyses. The results obtained from the acoustic analyses were in good agreement with the result of the experiment except for the very short length structures. This implies that the structure-passing wave can be modeled on a superposition of the pressure waves radiating from both sides of the structure.
\end{abstract}

Key Words : Pressure Wave, Low-frequency Noise, Over-bridge, Shinkansen, High-speed Railway

\section{1.はじめに}

近年話題となっている低周波音(1) (低周波空気振動) とは, 周波数が $1 \sim 100 \mathrm{~Hz}$ 程度の低い圧力変動を指し, 音としては知覚されにくいものの, 建具をガタつかせ たり，場合によっては圧迫感や耳鳴りなどの心理的影 響を及ぼしたりするものである.

鉄道線路の沿線で観測される低周波音としては，高 速列車がトンネルへ突入した時に，出口側の坑口から 外部へ放射されるパルス状の圧力波（トンネル微気圧 波 (2)）が代表的なものである. また，これ以外にもト ンネルを通過する際には，トンネル突入時に入口側の 坑口から発生するトンネル突入波 ${ }^{(3)}$, トンネル内を走 行中に継続的に発生するトンネル連続波 ${ }^{(4)}$, トンネル

* 原稿受付 2005 年 7 月 22 日.

*1 正員, 鉄道総合技術研究所(画 185-8540 国分寺市光町 2-838).

*2 正員, 広島大学大学院工学研究科( $\mathbb{E}$ 739-8527 東広島市鏡 山 1-4-1).

E-mail : takami@rtri.or.jp
退出時に出口側の坑口から発生するトンネル退出波 ${ }^{(3)}$ など, 様々な現象が発生する. これらトンネル通過に 伴って発生する低周波音に関しては, 現在までに多く の研究が実施されている.

一方，明かり区間（トンネル以外の区間）において は, 線路方向に短い構造物（例えば跨（こ）線橋：構 造物の軸方向長さが構造物断面直径の数倍程度以下) を高速列車が通過する際に, トンネルを通過する時と 同様な現象を起こすことが分かっている(ケ).ここで はこの現象を「構造物通過波」と呼ぶ. 現在, このよ うな構造物通過波が問題視されることはないが, 近年, 低周波音問題の関心が高まっており，さらに列車の高 速化が進めば問題となる可能性がある.

構造物通過波に関する既往の研究としては, 軸対称 数値計算( により, $500 \mathrm{~km} / \mathrm{h}$ 域の超高速列車が円筒状の 構造物を通過する際に構造物内で気柱共鳴が起こり, 周期的な圧力波を放射すると予測している. 一方, 現 地測定としては, 新幹線が掘割区間に架かる跨線橋を 通過する際に生じる圧力波について基本的な特性が調 


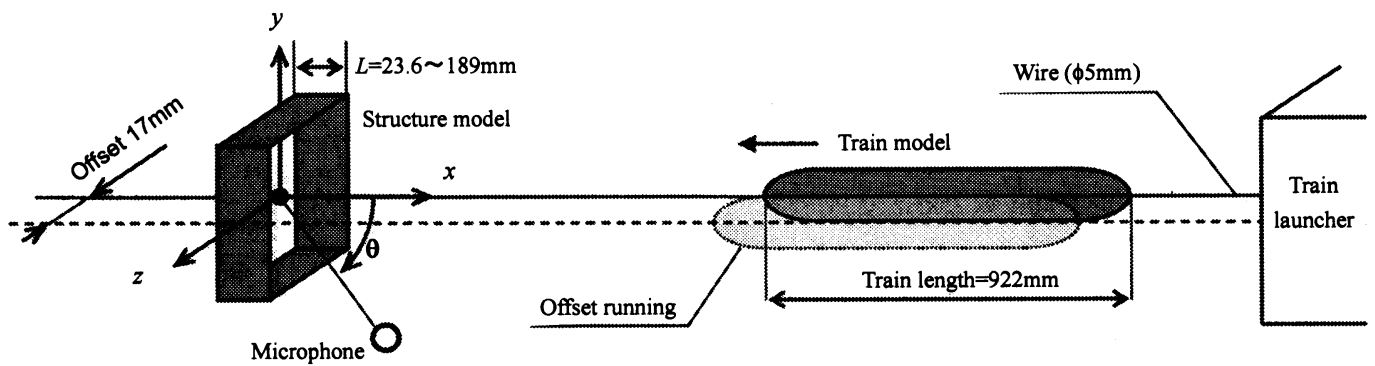

Fig.1 Experimental setup.

べられた(の.その報告においては,構造物通過波は $10 \mathrm{~Hz}$ 以下に主要な成分を持つパルス状の圧力波とされ，数 值計算( いた. ただし，現地の状況や列車速度が異なるため十 分に検証されたとは言えず，構造物通過波については 末だ不明な点が多い.

本論文では，主に跨線橋を想定した構造物通過波の 特性を，模型発射装置を用いて実験的に調べるととも に，構造物を円筒でモデル化した音響学的な解析を行 い,構造物通過波の基本的な発生メカニズムを調べた.

\section{2. 模 型 実 験}

$2 \cdot 1$ 実験方法 実験装置は図 1 に示すように, ピアノ線でガイドされた列車模型を構造物模型へ高速 で打ち込み，放射される圧力波をマイクロホンにより 計測するものである. この試験装置は, 以前より当研 究所でトンネル微気王波の研究に用いられており, 十 分な精度で現地の現象を模撖可能なことが確認されて いる(8).

模型実験の寸法関係を表 1 に示す. 座標系は右手系 にとり，原点を構造物中心におく．地面は鏡像法で模

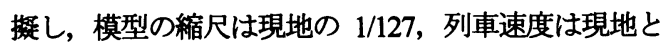
同程度とする. したがって, 現地と同じ速度条件にお いて発生する圧力波は, 振幅が現地と等しく, 周波数 は現地の 127 倍相当となる. 走行軸は構造物模型の中 心軸にそろえるケースと, 複線走行を模擬し左右に偏 心させるケースを行う.

列車模型の先頭部は，現車の断面積分布と相似形で ある. 先頭部は二種類用意し, 基本列車 Train- $\alpha$ 対し 比較列車 Train- $\beta$ は先頭部長さ $L_{n}$ が約 2.5 倍である. 列 車先頭部の断面積分布およひ変化率を図 2 に示す.こ こで, 左縦軸は列車先端からの位置 $x^{\prime}$ における列車断 面積 $A_{T}(x)$ であり，右䋛軸は列車断面積の変化率である. 構造物模型は現地の跨線橋と相似形の長方形断面で,
Table 1 Specifications of train and structure model.

\begin{tabular}{|c|c|c|c|}
\hline \multirow{3}{*}{$\begin{array}{l}\text { Train } \\
\text { model }\end{array}$} & \multicolumn{3}{|c|}{ Train length $=922 \mathrm{~mm}$} \\
\hline & Train- $\alpha$ & \multicolumn{2}{|c|}{$\begin{array}{l}\text { Nose length } L_{n}=47 \mathrm{~mm} \\
\text { Diameter }=42 \mathrm{~mm} \\
\text { Blockage(train } / \text { structure) }=0.14\end{array}$} \\
\hline & Train- $\beta$ & \multicolumn{2}{|c|}{$\begin{array}{l}\text { Nose length } L_{n}=118 \mathrm{~mm} \\
\text { Diameter }=40 \mathrm{~mm} \\
\text { Blockage(train } / \text { structure) }=0.13\end{array}$} \\
\hline \multirow{5}{*}{$\begin{array}{l}\text { Structure } \\
\text { model }\end{array}$} & \multicolumn{3}{|c|}{$\begin{array}{l}\text { Cross section: rectangular } 92.9 \times 103.9 \mathrm{~mm} \\
\text { Diameter of a circle having the same cross } \\
\text { sectional area: } d=110.9 \mathrm{~mm}\end{array}$} \\
\hline & \multicolumn{2}{|c|}{ Structure-A } & Length $L=23.6 \mathrm{~mm}, L d=0.21$ \\
\hline & \multicolumn{2}{|c|}{ Structure-B } & Length $L=47.2 \mathrm{~mm}, L / d=0.43$ \\
\hline & \multicolumn{2}{|c|}{ Structure-C } & Length $L=94.5 \mathrm{~mm}, L / d=0.85$ \\
\hline & \multicolumn{2}{|c|}{ Structure-D } & Length $L=189 \mathrm{~mm}, L / d=1.70$ \\
\hline $\begin{array}{l}\text { Circular } \\
\text { pipe }\end{array}$ & \multicolumn{3}{|c|}{$\begin{array}{l}\text { Cross section: circular, Diameter } d=100 \mathrm{~mm} \\
\text { Length } L=100 \mathrm{~mm}, L / d=1.00 \\
\text { Length } L=200 \mathrm{~mm}, L d d=2.00\end{array}$} \\
\hline
\end{tabular}

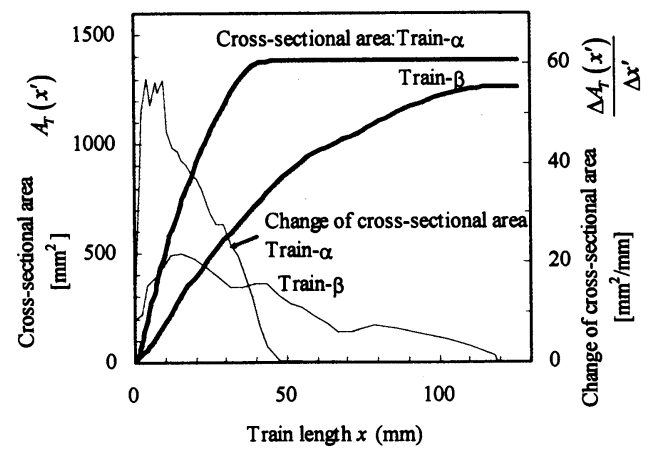

Fig.2 Distribution of model cross-sectional area.

軸方向長さは最も短い Structure-A から倍ずつの長さで Structure-D までの四種類である. また，3 章における 解析結果と比較を行うため, 断面が円形の円筒を構造 物とみなした実験も行った。 
$2 \cdot 2$ データ解析方法 音圧は侏リオン製の普通 騒音計 NL-20（有効周波数 $20 \sim 8,000 \mathrm{~Hz}$ ）を同時に 4 台用いて計測し, 必要な籄所の物理量を得るため, こ れらの騒音計は適宜移動した。計測データは, A/D変 換器を介してサンプリング周波数 $25 \mathrm{kHz}$ で $\mathrm{PC}$ 一記録 した. 得られた音圧データには, 主眼とする構造物通 過波に加え, 列車が観測点の近傍を通過することによ る非常に低い周波数の圧力変動(9)が重畳している. た だし,この圧力変動は主眼とする構造物通過波とは周 波数が離れているため, 本論文ではカットオフ周波数 500-5000Hz のバンドパスフィルタにより除去し, 構造 物通過波のみを抽出した。

抽出した構造物通過波には，正負のピークが複数現 れる.一般に，トンネルから放射される圧力波は片振 幅で評価されるが，構造物通過波は構造物の長さや列 車速度によって符号の異なる複数の圧力波が現れるた め, 沿線環境への影響を調べる場合には両振幅での評 価が適当と考えられる.このため本論文では, 列車が 構造物を通過する全時間において観測される圧力波の ピーク・ピーク値を, 構造物通過波の最大值として評 価する.

2-3 実験結果 代表的な観察波形を図 3 に示す. ただし, 前述したように列車周りに生じる圧力場の影 響は, フィルタ処理により除いている. 観測点は走行 軸と直角方向に構造物中心から $400 \mathrm{~mm}$ (現地換算約 $50 \mathrm{~m}$ ）離れた位置であり, 偏心走行は列車が観測点に 近づく場合である.

波形を見ると，短い構造物（Structure-A,B）では， 先頭部の突入時に負・正・負と続くパルス状の圧力波 が放射され，後尾部では反転して放射されている．ま た, 先頭部と比較し後尾部では, 流れの剥離の影響等 から圧力波が若干小さい，このような波形の形状は， 現地（Structure-B 相当）の実測結果 ${ }^{(6)}$ とほほ一致して おり, 実験の妥当性が確認できる. 一方, 比較的長い 構造物（Structure-C,D）では，圧力波の振幅および波 数がともに増加している. これに対応するような現地 の実測結果はないが，(振動的な圧力波は）軸対称数值 計算による結果 ${ }^{(9)}$ (Structure-C) と近い. また, 中心走 行と偏心走行を比較すると, 偏心走行の方が正負のピ 一クは大きくなっている. これは, 列車が偏心走行す ることでトンネル突入波・退出波に相当する圧力波が 列車偏心側の観測点で大きくなるとともに ${ }^{(10)}$, 偏心走 行により構造物内に形成される圧縮波（の圧力勾配）

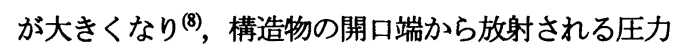
波も大きくなったためと考えられる.

次に, 列車種別による比較を行う。ここでは紙面の

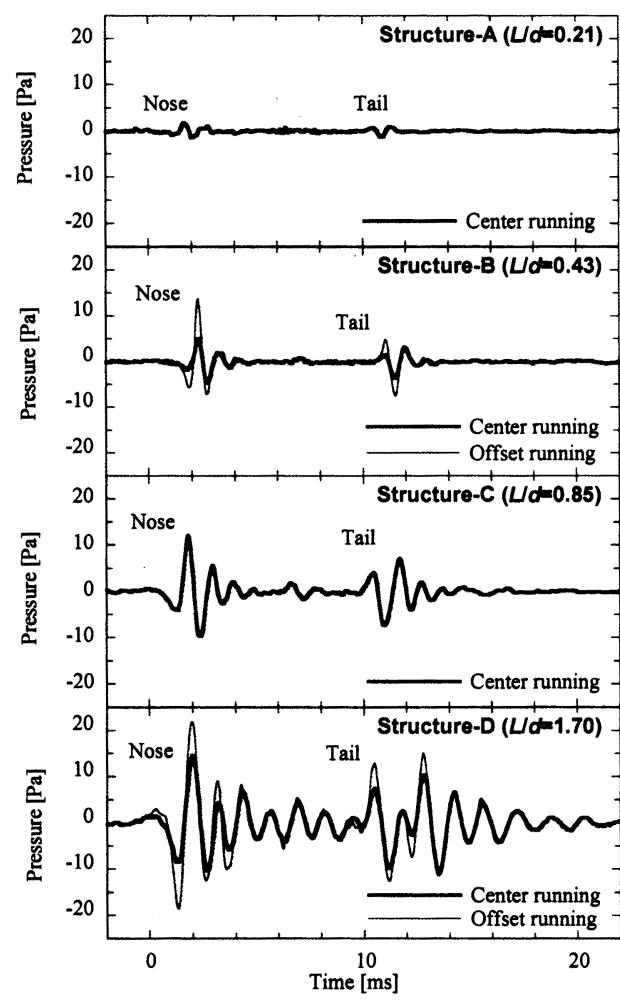

Fig.3 Pressure waves measured at train passage through structure.

[Train- $\alpha, U=350 \mathrm{~km} / \mathrm{h},(x, y, z)=(0,0,400 \mathrm{~mm})]$

Table 2 Comparison between Train- $\alpha$ and Train- $\beta$. [Structure-B, $U=350 \mathrm{~km} / \mathrm{h}$ ]

\begin{tabular}{|c|c|}
\hline & Ratio $\frac{\text { Train }-\beta}{\text { Train }-\alpha}$ \\
\hline Average of pressure magnitude & 0.3 \\
\hline Center running, $\quad(x, y, z)=(0,0,400) \mathrm{mm}$ & 0.34 \\
\hline$(x, y, z)=(0,231,400) \mathrm{mm}$ & 0.36 \\
\hline Offset-near, $\quad(x, y, z)=(0,0,400) \mathrm{mm}$ & 0.25 \\
\hline$(x, y, z)=(0,0,400) \mathrm{mm}$ & 0.35 \\
\hline Max cross-sectional area & 0.91 \\
\hline Max. change of cross-sectional area & 0.38 \\
\hline
\end{tabular}

都合から波形は示さないが, 基本車両 Train- $\alpha$ と比較車 両 Train- $\beta$ (先頭部が長い) で発生する圧力波を比べる と，その波形形状は似ているが振幅は Train- $\beta$ が小さく なる. 構造物 Structure-B ・ 速度 $350 \mathrm{~km} / \mathrm{h}$ における結果 をまとめると（表 2），圧力波の振幅比はおおむね Train- $\beta /$ Train- $\alpha=0.3$ 程度となる. 一方, 車両形状を比較 すると,断面積比は 0.9 程度とほとんど变わらないが, 断面積の変化率比は 0.3 程度と圧力波の低减比に近い. 


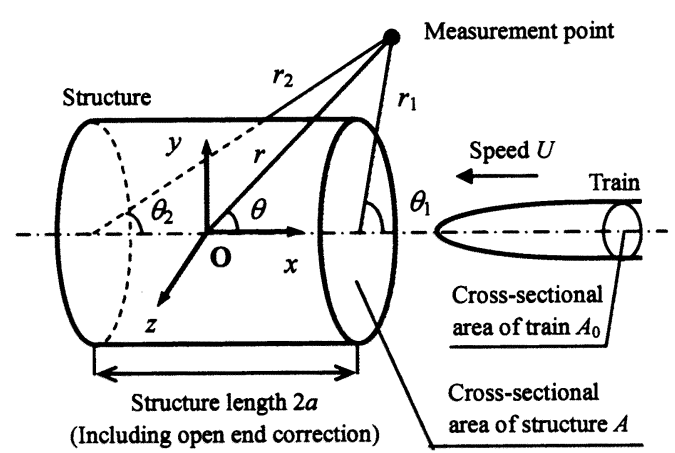

Fig.4 Analytical model.

トンネル微気压波の対策 ${ }^{(1)}$ から類推すれぼ, 構造物通 過波を低减するには，列車断面積よりも断面積変化率 を抑える対策が有効と考えられる.

なお，構造物通過波の速度乗則，距離减衰および構 造物の長さとの関係については, 後述する解析結果と 合わせて 4 章に示す.

\section{3. 音辢学的な解 析}

構造物が比較的長い場合は，構造物通過波はトンネ ル坑口からの放射波に類似した現象と考えられるので, トンネルに対して用いられている解析モデルの適用を 試みる. 図 4 に，構造物を円筒でモデル化し，中心走 行を行った場合の解析モデルを示す. 先頭部の突入・ 退出の現象に注目し, 列車は半無限長とする. 座標系 は右手系にとり，原点を構造物中心におく．まず始め に, 列車が円筒状の構造物一突入する時に構造物内部 に形成される圧縮波を, Howe らの音響学的予測手法 (12)により求める. この解析では，以下の条件を前提と

している.

(1) 形成される圧縮波波面の空間幅が，構造物断面の スケールよりも数倍以上大きいこと. すなわち, 構造物断面が音響学的にコンパクトであること.

(2) 構造物の列車退出側端部（図 4 における左端部） 付近で評価したときに，圧縮波の波面がほぼ平面 波とみなせること.

(3) 圧縮波の先頭波面が開口端反射により突入側に戻 った時点で, 圧縮波の形成が完了していること.

ここで, 条件1ににいては, マッ八数 0.4 以下の鉄道 では, 極端に大きな断面を持つ構造物でなければ満た される. 条件(2)については, 理論解析 ${ }^{(13)}$ や $\mathrm{CFD}^{(11)}$ 結果 から, 構造物の長さが構造物断面直径の 1.5 倍程度以 上あれば $(L / d>1.5)$, 退出側端部の圧縮波はほほ平

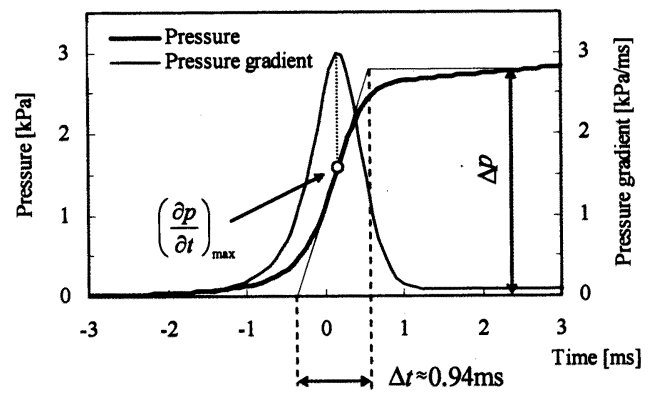

Fig.5 Compression wave and pressure gradient obtained by analysis. [circular pipe, center running, Train- $\alpha$, $U=350 \mathrm{~km} / \mathrm{h}]$

面波とみなせる. 条件(3については，先頭波面が構造 物を往復する時間と圧縮波の形成にかかる時間との間 に, 以下の関係が必要である.

$$
\frac{2 L}{c_{0}}>\Delta t \quad \text {, すなわち } \frac{L}{d}>\frac{c_{0} \Delta t}{2 d}
$$

ここで, $L:$ 構造物の軸方向長さ, $c_{0}$ : 音速, $\Delta t:$ 圧縮 波の特性的な時間幅 ${ }^{(14)(15)}$ である.

以上の適用条件を満たす場合, 列車の突入により構 造物内部に形成される圧縮波は次式で示される.

$$
\begin{aligned}
p_{e n}([t])= & \frac{\rho_{0} U^{2}}{A\left(1-M^{2}\right)}\left(1+\frac{A_{0}}{A}\right) \\
& \int_{-\infty}^{\infty} \frac{\partial A_{T}}{\partial x^{\prime}}\left(x^{\prime}+U[t]\right) \frac{\partial \varphi^{*}}{\partial x^{\prime}}\left(x^{\prime}, 0,0\right) d x^{\prime}
\end{aligned}
$$

ここで, $p_{e n}$ : 突入時の構造物内圧力, $[t]=t-|x-a| c_{0}$ : 遅 延時間, $t$ : 時間, $\rho_{0}$ : 空気密度, $A$ : 構造物断面積, $M$ : 突入マッ八数, $x^{\prime}:$ 列車の先頭から後尾へ向かう座 標, $U$ : 列車速度, $\varphi$ : 構造物の形状から決まる速度 ポテンシャル（ここでは構造物をフランジの無い薄肉 円筒と仮定し解析解を用いるが，任意形状の構造物に 対しては数值計算により求められる) である. 式(2)に より求めた圧縮波形および圧力勾配の一例を図 5 に示 す。なお，圧縮波の特性的な時間幅 $\Delta$ は，図 5 に示す ように圧縮波の最大圧力と見なせる $\Delta p$ と圧力勾配の 最大值から, $\Delta t=\Delta p /(\partial p / \partial t)_{\max }$ として求められる(1). 次に, 構造物から外部一放射する圧力波を求める. 構造物の端部にフランジがなく，地面の影響を鏡像で 表現すると，構造物外部空間を無限領域と見なすこと ができる. 列車は構造物の中心軸に沿って突入するも のとし, 観測点は遠方場とする. 以上の条件の場合， 先頭部の突入によって放射される突入波 $P_{e n}{ }^{\prime}$ は, 式(2) 


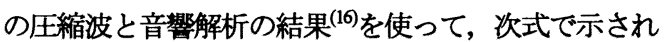
る.

$$
P_{e n}{ }^{\prime}=-\frac{A}{4 \pi c_{0}} \frac{1}{r_{1}}\left(1-\cos \theta_{1}\right) \frac{\partial p_{e n}}{\partial t}
$$

ここで, $r_{1}$ : 構造物入口から観測点までの距離， $\theta_{1}$ : 列車の先頭から後尾一向かう方向と構造物入口から観 測点に向から方向がなす角度である.

さらに式(2)の圧縮波が構造物内を伝播し, 両端で放 射・反射を絽り返す際の現象が微気圧波である.この 微気圧波についても音響解析(2)を行い, 式(3)と重畳さ せることで, 列車の突入により構造物から外部一放射 される圧力波 $P_{e n}$ を次式で表す。

$$
\begin{gathered}
P_{e n}(t)=-\frac{1}{r_{1}}\left(1-\cos \theta_{1}\right) \frac{A}{4 \pi c_{0}} \frac{\partial p_{e n}}{\partial t}\left(t-\frac{r_{1}}{c_{0}}\right) \\
+\frac{2}{r^{*}} \sum_{n=1}^{\infty}(-\gamma)^{n-1} \frac{A}{4 \pi c_{0}} \frac{\partial p_{e n}}{\partial t}\left(t-\frac{r^{*}}{c_{0}}-n \frac{2 a}{c_{0}}\right) \\
r^{*}= \begin{cases}r_{1}, & n=\text { 偶数 } \\
r_{2}, & n=\text { 奇数 }\end{cases}
\end{gathered}
$$

ここで, $r_{2}$ : 構造物出口から観測点までの距離， $\gamma:$ 開 口端反射に伴う减衰保数, $2 a$ : 開口端補正を含む構造 物の長さ, $n$ :反射回数である. なお, 開口端反射に伴 う减衰係数 $\gamma$ は, 開口部の形状や圧力波に含まれる周 波数成分に影響を受け，さらに列車が構造物を通過中 （串刺し状態）の反射となるので，本稿では実験から 推定する.

同様の考え方で, 列車の退出により構造物内に生じ る圧縮波 $p_{\mathrm{ex}}$ から, 構造物から外部一放射される圧力波 $P_{e x}$ を求める.

$$
\begin{gathered}
P_{e x}(t)=-\frac{\alpha}{r_{2}}\left(1+\cos \theta_{2}\right) \frac{A}{4 \pi c_{0}} \frac{\partial p_{e x}}{\partial t}\left(t-\frac{r_{2}}{c_{0}}-\frac{2 a}{U}\right) \\
+\frac{2 \alpha}{r^{*}} \sum_{n=1}^{\infty}(-\gamma)^{n-1} \frac{A}{4 \pi c_{0}} \frac{\partial p_{e x}}{\partial t}\left(t-\frac{r^{*}}{c_{0}}-n \frac{2 a}{c_{0}}-\frac{2 a}{U}\right) \\
r^{*}= \begin{cases}r_{1}, & n=\text { 奇数 } \\
r_{2}, & n=\text { 偶数 }\end{cases}
\end{gathered}
$$

ここで, $\alpha$ : 以下で述べる退出時圧縮波の倸数, $\theta_{2}:$ 列 車の先頭から後尾へ向かう方向と構造物出口から観測 点に向かう方向がなす角度, $p_{e x}$ : 退出時の構造物内圧 力である. 列車の退出により構造物内に形成される圧 縮波 $p_{\mathrm{ex}}$ は, 列車の突入により形成される圧縮波 $p_{e n}$ と 一般には異なるため, 本稿では突入時の圧縮波 $p_{e n}$ に係 数 $\alpha$ を掛けたもので近似する. この係数 $\alpha$ は, トンネ ルのように十分長く列車周りの圧力分布がほぼ定常と

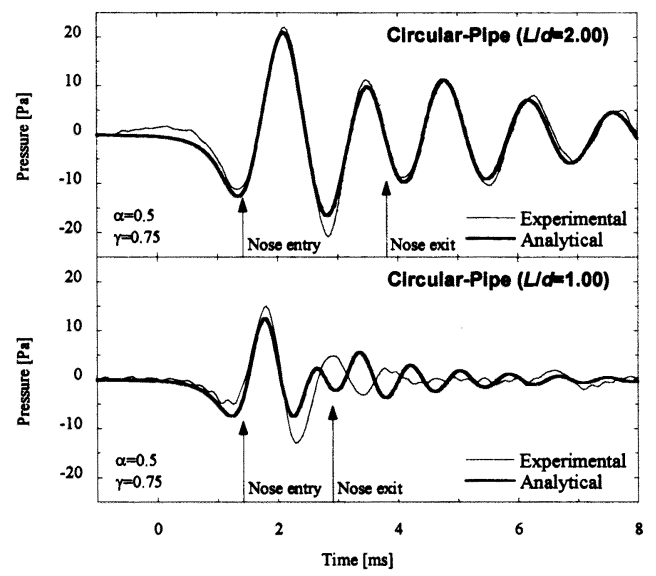

Fig.6 Comparison of pressure waves between experiment for a circular cross-section and analysis. [center running, Train- $\alpha, U=350 \mathrm{~km} / \mathrm{h},(x, y, z)=(0,0,400 \mathrm{~mm})]$

なった状態では，一定值に近づくと考えられる。しか し, 構造物が短、場合, 列車周りの流れは僄移状態に あり，構造物の長さや列車速度により係数 $\alpha$ は異なる ため, 本稿では実験から推定する. 以上により, 列車 の突入・退出にともない構造物から外部一放射される 圧力波 $P_{e n}$ および $P_{e x}$ を式(4)(5)から求め, それらを重畳 させることで構造物通過波を表す。

ここで, 解析モデルの断面形状は跨線橋と異なり円 形のため，まず始めに，円筒による模型実験と解析結 果の比較を図 6に示す.俰数は $\alpha=0.5, \gamma=0.75$ である. この結果から, 上段に示す円筒 $(L / d=2)$ では, 実験と解 析結果は良く一致する一方, 下段に示すようなより短 い円筒 $(L / d=1)$ では, 解析の誤差が大きい. この理由と して, 構造物が極端に短い場合, 解析の適用条件(3に おける式(1) (圧縮波の時間幅 $\Delta t$ を図 5 より $0.94 \mathrm{~ms}$ 程 度と見積もれば $L / d>1.6)$ を満たさないことが考えら れる. 一方, 式(1)を含む適用条件が全て成り立つ $L / d=2$ の円筒では, 実験結果と解析結果が良く一致すること から, 解析モデルの妥当性が確認できる.

このため以降では, $L / d=1.7$ の比較的長い構造物 Structure-D（断面形状は長方形）について詳細に解析 を実施した. 実験結果と解析結果の比較を図 7 に示す. ここで, 上段の図は解析における式(4)および式(5)の各 項を分けてプロットしたものであり，それらを重畳さ せたものが下段の解析波形である，なお，解析モデル は図4に示したように円筒のまま，長方形断面の構造 物を等価な断面積を持つ円筒とみなした，図 7 の結果 から，断面形状が長方形であっても解析と実験結果は 


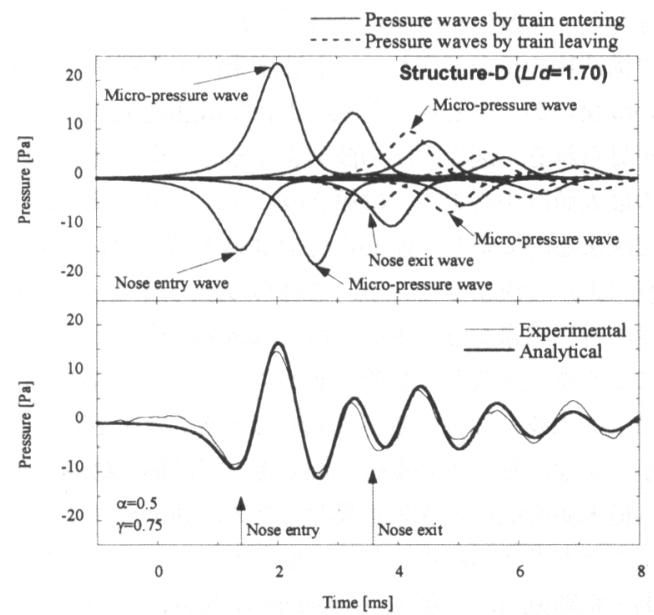

Fig.7 Comparison of pressure waves between experiment for a rectangular cross-section and analysis. [center running, Train- $\alpha, U=350 \mathrm{~km} / \mathrm{h},(x, y, z)=(0,0,400 \mathrm{~mm})]$

良く一致し，円筒モデルによる音響学的な解析が模型 実験の結果を説明できること分かる．すなわち，比較 的長い構造物における構造物通過波は，構造物の両端 から放射される圧力波の重畳として表せる.

式(4)(5)に基づく音響学的な解析により求めた $x$-z 断 面（ただし $y=0, z \geq 0 ）$ の圧力分布を図 8 に示す. 列車 は図の右から左に向かって走行し（時系列は上から下 の順), $(x, y, z)=(0,0,0)$ に中心をおく Structure-D を通過 する. ただし，この図は流体数值シミュレーションの 結果ではないので, 列車近傍の流体力学的な圧力分布 は含まれていないことに注意されたい. 列車の走行に ともない, 構造物の両端から突入波, 退出波, 微気圧 波および反射による微気圧波が放射し重畳することで, 構造物通過波は観測点によって複雑な変動を示すこと が図から分かる.

\section{4. 構 造 物 通過波 の 特 性}

構造物通過波の最大値 (ピーク・ピーク值, 2.2 節参 照）と列車速度の関係を図 9 に, 観測距離との関係を 図 10 にそれぞれ示す．観測点は構造物の中心線上 $(x$, $y)=(0,0)$ である. まず始めに, 解析結果と対応する中心 走行・Structure-D について述い゙る. 図 9 の速度特性を 見ると, 列車速度が高いほど構造物通過波も大きくな り，その乗則は実験および解析結果はともに 4 乗程度 でほぼ一致する. 次に, 図 10 の距離减衰を見ると, 実 験および解析結果はともに-0.9 乗程度で一致し, 点音
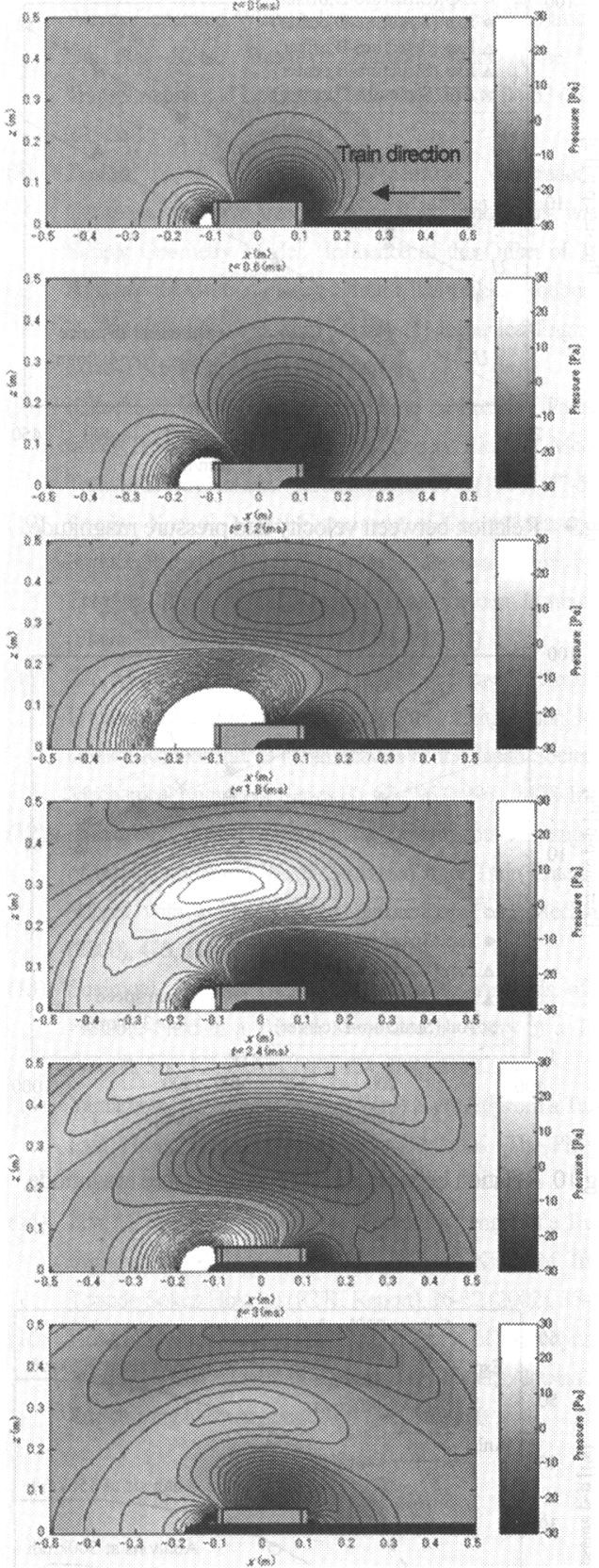

Fig.8 Instantaneous acoustic pressure distribution obtained by analysis.

[Structure-D,center running, Train- $\alpha, U=350 \mathrm{~km} / \mathrm{h}$ ] 


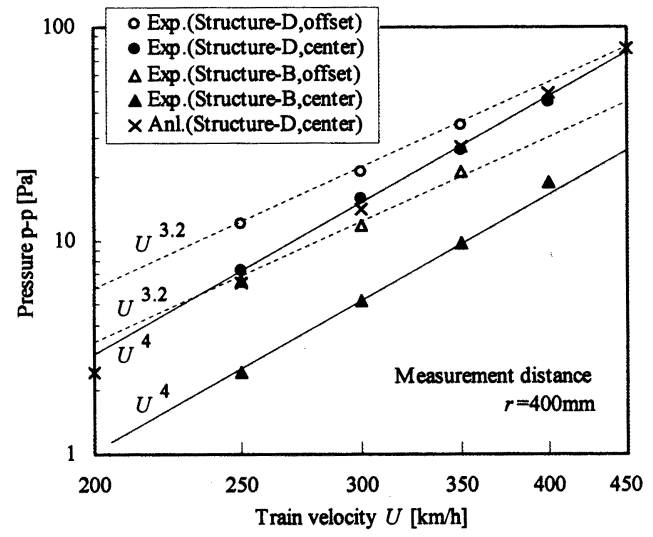

Fig.9 Relation between velocity and pressure magnitude.

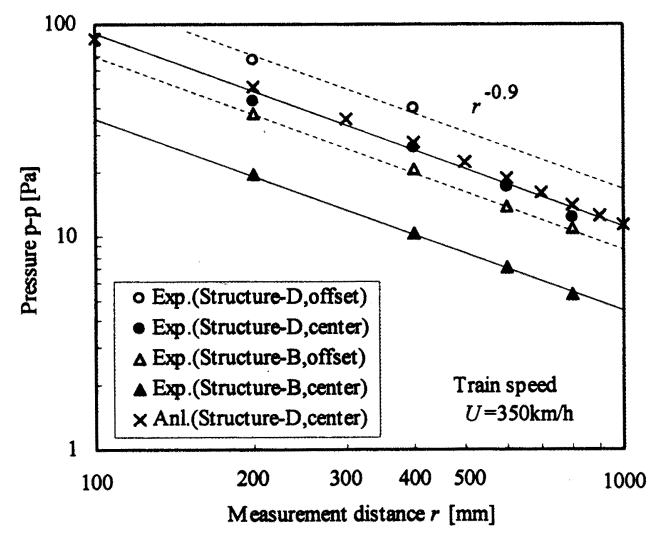

Fig.10 Relation between distance and pressure magnitude.

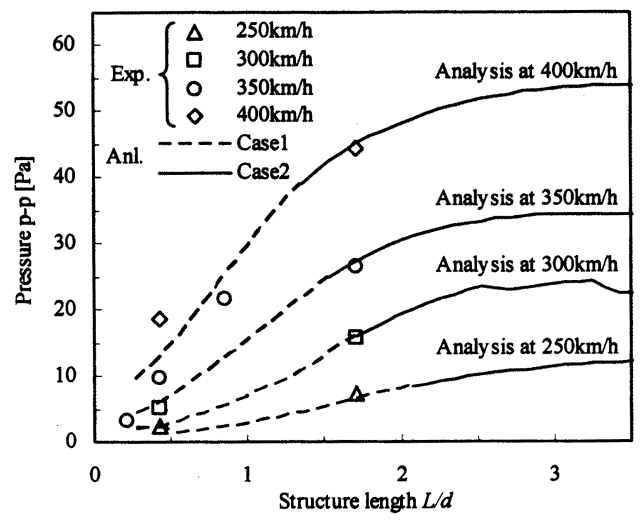

Fig.11 Relation between structure length and pressure magnitude. $[(x, y, z)=(0,0,400 \mathrm{~mm})]$
源からの音波の距離减衰にほぼ合致する.一方, 図 9,10 で構造物の長さが変わっても速度乗則・距離减衰に違 いはないが, 中心走行と偏心走行では速度乗則に違い が見られる. 図3 圧力波形を見ると, 構造物通過波 の最大值は中心走行では第 2 波（正）と第 3 波（負） で決まるのに対し，偏心走行では第 1 波（負）と第 2 波（正）で決まっている。.これらの圧力波は, 図7上 段の解析結果から, 中心走行では微気圧波とその反射 による微気圷波が支配的であることを示し, 偏心走行 では突入波と微気死波が支配的であることを示してい る. すなわち, 中心走行と偏心走行では構造物通過波 の最大值を決める現象が異なるため, 速度乗則に差が 現れたと考えられる. なお, 偏心走行における速度乗 則・距離减衰は, 現地 (Structure-B 相当, 偏心走行) の実測結果 ${ }^{(6)}$ とほほ等しい.

次に，構造物通過波の最大值と構造物の長さとの関 係を図 11 に示す. 観測点は構造物の中心線上の $(x, y$, $z)=(0,0,400 \mathrm{~mm})$ である.ここで, プロットは実験結果を, 破線は解析の適用条件(3)における式(1)を满たさない 解析結果 (以降 Case1：解析適用外のため誤差が大き い)を，実線は式(1)を满たす解析結果（以降 Case2） を示す. 図 11 の結果から, 構造物が長くなるにしたが い構造物通過波は大きくなるが，ある程度の長さで最 大值をとる傾向が分かる. この傾向は，それぞれの Caseで次のように説明できる.

Case1 の範用では，構造物が長くなるにしたがい列 車の突入・退出により構造物内に生じる圧縮波そのも のが大きくなる. 一方, 構造物通過波の大きさは, 構 造物の両端から放射される圧力波の重ね合わせで決ま るが，それらの圧力波は常に符合が異なるため打ち消 しあう傾向にある (図7参照). 例えば, 第 1 波は先頭 部突入時の突入波で負, 第 2 波は出口側からの微気圧 波で正，第3 波は反射による入口側からの微気圷波で 負である. しかしながら，構造物が長くなると圧力波 を放射する時間間隔は離れ，打ち消しあいが少なくな る. この様な理由により, Case1 では構造物が長くな ると, 構造物通過波は急激に大きくなる. 構造物の長 さが Case2 に達すると，構造物内に生じる圧縮波は飽 和するが，引き続き圧力波の打ち消しあいは少なくな り，構造物通過波は紸やかに大きくなる. 一方で, 構 造物が長くなると構造物の開口部と観測点は離れ，圧 力波は距離减衰により小さくなる.このため, ある程 度の構造物長さで最大值をとると考えられる. 


\section{5. まとめ}

主に跨線橋を想定した構造物通過波を, 模型実験お よび音響学的な解析により調べ，その特性を明らかに した.

（1）列車が構造物を通過する際には，構造物が長く， 列車速度が高くなるにしたがい, ピークが大きく 比較的周期性を持つ圧力波 (構造物通過波) が放 射されるようになる.

（2）圧力波の大きさは中心走行において列車速度の 4 乗程度, 観測距離の-0.9 乗程度, 偏心走行におい て速度の 3 乗程度, 観測距離の-0.9 乗程度に比例 する.

（3）解析の適用条件を満たす構造物においては, 構造 物を円筒でモデル化した音響学的な解析により 現象を予測できる.すなわち，構造物通過波は， 構造物の両端部から放射される圧力波 (突入波, 退出波, 微気圷波, 反射による微気圧波) の重鲳 として表せる.

最後に, 本研究の模型実験にあたっては, 琍テス鈴 木孝康氏にお世話になった. ここに記し感謝の意を表 する.

\section{文 献}

(1) Ministry of the Environment, Manual of Low-frequency noise problem (in Japanese), (2004).

(2) Ozawa, S., Studies of Micro-pressure Wave Radiated from a Tunnel Exit, Tetsudo Gijutu Kenkyu Hokoku (Railway Technical Research Repot), 1121 (1979).

(3) Iida, T. et al, Numerical Analysis of the Pressure Wave Radiated from the Entrance when a Train Enters a Tunnel, Nihon Kikai Gakkai Ronbunshu, B (Transactions of the Japan Society of Mechanical Engineers, Series B), 66-651 (2000), 2861-2868.

(4) Nakatani, K. et al, Continuous Pressure Waves Radiated from Shinkansen Tunnels, Nihon Kikai Gakkai Dai73ki Tsujosokai Koen Ronbunshu, III (Proceedings of the 73rd JSME Spring Annual Meeting, III), 96-1 (1996), 333-334.

(5) Ogawa, T. and Nishida, T., Numerical Investigation of a Pressure Wave Generated by a High-Speed Train Passing Through a Structure, Forum Acusticum, (2002)

(6) Kikuchi, K. et al, Field Measurement of Pressure Waves Observed When a Train Passes an Over-Bridge, Nihon Kikai Gakkai Ronbunshu, B (Transactions of the Japan Society of Mechanical Engineers, Series B), 70-691 (2004), $672-677$.
(7) Takami, H. et al, Experimental Measurement of Pressure Waves Generated When a Train Passes Through a Structure, Dail3kai Kotsu Butsuryu Bumon Taikai (The 13th Transportation and Logistics Conference 2004), 04-53 (2004), 285-288.

(8) Tanaka, Y. et al, Method to Simulate Generation of Compression Wave Inside a Tunnel at Train Entry with a Simple Geometry Model. (Influence of the Offset of Train Axis and the Ground Place), Nihon Kikai Gakkai Ronbunshu, B (Transactions of the Japan Society of Mechanical Engineers, Series B), 69-683 (2003), 1607-1614.

(9) Kikuchi, K. et al, Numerical Analysis of Pressure Variation under Train Passage using the Boundary Element Method, Tetsudo Soken Hokoku (RTRI Report), 10-2 (1996), 47-52.

(10) Tanaka, Y. et al, Model Experiment of Countermeasures to Reduce Pressure Waves Generated Outside a Tunnel by an Entering Train, Ryutai Kogaku Bumon Koen Ronbunshu (Fluids Engineering Conference), 01-3 (2001).

(11) Iida, M. et al, Optimization of Train Nose Shape for Reducing Impulsive Pressure Wave from Tunnel Exit, Nihon Kikai Gakkai Ronbunshu, B (Transactions of the Japan Society of Mechanical Engineers, Series B), 62-596 (1996), 1428-1435.

(12) Howe, M.S. et al, Theoretical and Experimental Investigation of the Compression Wave Generated by a Train Entering a Tunnel with a Flared Portal, Journal of Fluid Mechanics (2000), 425, 111-132.

(13) Sugimoto, N. and Ogawa, T., Acoustic Analysis of the Pressure Field in a Tunnel, Generated by Entry of a Train, Proc. R. Soc. Lond. A(1998), 454, 2083-2112.

(14) Yamamoto, A., Micro-pressure Wave Radiated from a Tunnel Exit, Nihon Butsuri Gakkai Haru Bunkakai (The Physical Society of Japan Spring Meeting), (1977)

(15) Iida, M. et al, Estimation of the Necessary Length of a Tunnel Entrance Hood Entered into by Different Kinds of Trains, Tetsudo Soken Hokoku (RTRI Report), 16-12 (2002), 35-40.

(16) Howe, M. S., Vorticity and the Theory of Aerodynamic Sound, Third Lighthill Memorial Paper, Joumal of Engineering Mathematics (2001), 41, 367-400. 